\title{
Matching zooplankton abundance and environment in the South Indian Ocean and Southern Ocean
}

\author{
Claire Godet $^{\mathrm{a}}$, Marine Robuchon ${ }^{\mathrm{a}, \mathrm{b}, \mathrm{c},{ }^{*}, \text { Boris Leroy }^{\mathrm{a}} \text {, Cédric Cotté }}{ }^{\mathrm{d}}$, Alberto Baudena ${ }^{\mathrm{d}, \mathrm{e}}$, \\ Ophélie Da Silva ${ }^{\mathrm{e}, \mathrm{f}}$, Salomé Fabri-Ruiz ${ }^{\mathrm{e}}$, Claire Lo Monaco ${ }^{\mathrm{d}}$, Sara Sergi ${ }^{\mathrm{d}}$, Philippe Koubbi ${ }^{\mathrm{g}}$, h \\ ${ }^{\text {a }}$ Laboratoire de Biologie des Organismes et écosystèmes Aquatiques (BOREA), Muséum National d'Histoire Naturelle, CNRS, IRD, Sorbonne Université, Université de \\ Caen Normandie, Université des Antilles, CP 26, 57 Rue Cuvier, 75005, Paris, France \\ ${ }^{\mathrm{b}}$ Centre d'Ecologie et des Sciences de la Conservation (CESCO), Muséum National d'Histoire Naturelle, CNRS, Sorbonne Université, CP 135, 57 Rue Cuvier, 75005, \\ Paris, France \\ ${ }^{c}$ Joint Research Centre (JRC) of the European Commission, Directorate for Sustainable Resources, Ispra, Italy \\ ${ }^{\mathrm{d}}$ Sorbonne Université UMR 7159 CNRS-IRD-MNHN, LOCEAN-IPSL, 75005, Paris, France \\ e Laboratoire D'Océanographie de Villefranche-sur-Mer, UMR 7093 - CNRS/UPMC, 181 Chemin Du Lazaret, 06230, Villefranche-sur-Mer Cedex, France \\ ${ }^{\mathrm{f}}$ Institut de Systématique, Evolution, Biodiversité (ISYEB), Muséum National d'Histoire Naturelle, CNRS, Sorbonne Université, EPHE, Université des Antilles, CP 50, 57 \\ Rue Cuvier, 75005, Paris, France \\ ${ }^{\mathrm{g}}$ UFR918 Terre, Environnement, Biodiversité. Sorbonne Université, 4 Place Jussieu, 75252, PARIS Cedex 05, France \\ ${ }^{\mathrm{h}}$ IFREMER Centre Manche Mer Du Nord - 150, Quai Gambetta, 62200, Boulogne-sur-Mer, France
}

\section{A R T I C L E I N F O}

\section{Keywords:}

Bioregionalization

Southern Ocean

Indian Ocean

Pelagic ecosystem

Zooplankton

Continuous plankton recorder

\begin{abstract}
A B S T R A C T
Distinguishing regions based on the geographic distribution of both abiotic factors and living organisms is an old but still actual central issue for biogeographers. In the Southern Ocean, the few existing regionalization studies have been carried out either at very large scales or on the relatively small region around the Sub-Antarctic islands of Kerguelen and the Crozet archipelagos. However, regionalization studies at meso-scales (100-300 km) covering the Indian part of the Southern Ocean and adjacent South Indian Ocean are scarce. These waters, ranging from the Subtropical to the polar region, are home to large populations of well-studied top predators that depend on the biomass of less known mid-trophic level species such as zooplankton. To fill those gaps, our study aims at conducting bioregional analyses of this transition area at the meso-scale based on the distribution of abiotic factors and chlorophyll- $a$, and to investigate how the abundance of zooplankton varies across the bioregions identified. To that end, we first characterized epipelagic bioregions $30^{\circ} \mathrm{S}$ in the South Indian Ocean to $65^{\circ} \mathrm{S}$ in the Southern Ocean and from $40^{\circ}$ to $85^{\circ} \mathrm{E}$ including the islands of Crozet, Kerguelen, Saint-Paul and New Amsterdam. We then determined whether these bioregions correspond to variations in the abundance of zooplankton collected by a Continuous Plankton Recorder. Finally, we analyzed which environmental parameters influence zooplankton abundance. Our analyses evidenced six regions, providing a synthetic overview of a contrasting environment. The spatial variability of zooplankton abundance was explained by most of the environmental variables used in the bioregionalisation and, to a lesser extent, by the bioregions. Copepods are abundant in the colder and physically-energetic regions associated with the Antarctic Circumpolar Current (ACC). Limacina and euphausids are both abundant in regions characterized by a high concentration of chlorophyll- $a$, although euphausids are also abundant in the subtropical region. This work represents a crucial step forward in the integration of living organism distribution in the regionalization of the Indian part of Southern Ocean and adjacent South Indian Ocean. This can, ultimately contribute to the optimization of marine conservation strategies.
\end{abstract}

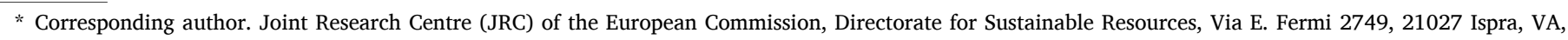
Italy.

E-mail address: marine.robuchon@ec.europa.eu (M. Robuchon).
} 


\section{Introduction}

Marine ecoregionalization is a process that aims to divide oceanic areas into distinct spatial regions, using a range of abiotic and biotic such as chlorophyll- $a$ and species assemblages - information (Foster et al., 2017; Hill et al., 2017; Koubbi et al., 2010, 2011; Spalding et al., 2007). When data on species assemblages are not sufficiently available to identify ecoregions accurately, bioregions (Grant et al., 2006) or biogeochemical regions (Longhurst, 2010) can be identified based on the distribution of abiotic factors and chlorophyll- $a$ only, i.e. available satellite gridded products. The process results in a set of bioregions, each with relatively homogeneous and predictable ecosystem properties (Grant et al., 2006). Bioregions can be divided at different spatial scales, depending on their physical and environmental characteristics. Bioregions are considered as a proxy of biodiversity spatial patterns through an objective zoning. They constitute a basis for understanding, conserving and managing activities in the marine environment (Grant et al., 2006; Ainley et al., 2010; Hogg et al., 2018).

Several studies have proposed regionalizations based on the biogeochemical, hydrological or physical and geographical characteristics of the oceans including the Southern Ocean (Grant et al., 2006; Longhurst, 2010; Raymond, 2014; Reygondeau and Huettmann, 2014). Four biogeochemical provinces have been identified in the Southern Ocean (Longhurst, 2010) from publications on satellite observations, oceanographic and biotic observations on chlorophyll-a, phytoplankton or zooplankton collected during oceanographic surveys. Major changes in these biogeochemical provinces are projected by modeling studies, including southward shifts of the provinces and changes in their areas (Reygondeau and Huettmann, 2014). Changes in the Southern Ocean are mainly imputed to the consequences of human activities, both direct (exploitation of living resources by fishing) and indirect (increase in temperature, seasonality of sea ice, ocean acidification; Constable et al., 2014; Turner et al., 2014; IPCC, 2019). These alter the functioning of marine systems and food webs because they induce habitat modifications, which affect primary producers up to top predators, coastal organisms down to deep species, and the Sub-Antarctic Zone up to the sea ice zone (Constable et al., 2014; Gutt et al., 2015).

However, the existing Southern Ocean regionalizations (Grant et al., 2006; Raymond, 2014) did not consider regional features such as phytoplankton plumes linked to island effects and did not include seasonality. In addition, their northern limit $\left(40^{\circ} \mathrm{S}\right)$ excluded the Subtropical zone. This paper proposes to delimit bioregions for the South Indian Ocean and the Southern Ocean covering the area between $40^{\circ} \mathrm{E}$ and $85^{\circ} \mathrm{E} ; 30^{\circ} \mathrm{S}$ and $65^{\circ} \mathrm{S}$. These include the islands of Crozet, Kerguelen, Saint Paul and New Amsterdam. These islands are linked to important topographic features, the ridges of southwest and southeast Indian Del Cano elevation, Crozet Islands' shelf (archipelago) and the Kerguelen Plateau. The occurrence of different water masses and the interaction of the intense ACC with these bathymetric features contribute to the heterogeneity of the region, both from an hydrodynamical point of view and for the subsequent distribution of biogeochemical properties (Roquet et al., 2009; Sokolov and Rintoul, 2007). In this area, the large-scale distribution of primary production and top predators are well known, respectively from remote sensing and biologging data (Cotté et al., 2007; Bost et al., 2009; De Monte et al., 2012; Gandhi et al., 2012; Ropert Coudert et al., 2014). However, very few studies have examined the regional distribution of zooplankton and intermediate trophic levels such as micronekton which includes small organisms $(\sim 1-20 \mathrm{~cm}$ or g) that can swim (Koubbi, 1993; Handegard et al., 2013; Duhamel et al., 2014; Lehodey et al., 2015; Béhagle et al., 2016; Venkataramana et al., 2019). In addition, the main studies on plankton have been mostly conducted in around Kerguelen, either in the coastal zone, above the island shelf or on the eastern edge of the plateau (Blain et al., 2007; Pollard et al., 2007; Sanial et al., 2014).

Sampling devices gathering large scale zooplankton information, like the Continuous Plankton Recorder (CPR), can survey vast geographical region to study zooplankton distribution (Batten et al., 2019). This plankton sampling device continuously collects organisms all along a cruise track at the sub-surface and has already been deployed in the Southern Ocean for past studies (Hosie et al., 2003, 2014). The CPR was deployed for the first time in the South Indian Ocean and the Southern Ocean in 2013 on board the R/V "Marion Dufresne" (Meilland et al., 2016) and since then the surveys have been carried out every year between January and February (Fig. 1). These new samples at high spatial resolution fill a geographic gap in both the South Indian Ocean and the Southern Ocean.

Therefore, the objectives of this study were (i) to delimit and characterize bioregions in this area and (ii) to verify whether variations in the abundance of zooplankton can be explained by the environmental characteristics of the bioregions. Specifically, we wanted to define these bioregions at the mesoscale $(100-300 \mathrm{~km})$ to provide a better representation of oceanographic features, such as water mass dynamics and fronts. To attain our general objectives, we first delimited summer pelagic bioregions on the basis of environmental parameters (sea surface temperature, chlorophyll- $a$ concentration, kinetic energy and bathymetry) describing the main characteristics of the region analyzed. Then, we determined whether these bioregions were precise predictors of variations in zooplankton abundance in the Southern Ocean and the South Indian Ocean by using samples collected by the CPR. Finally, we investigated the extent to which changes in zooplankton abundance were explained by the environmental characteristics of bioregions.

\section{Materials and methods}

\subsection{Bioregionalization}

\subsubsection{Study area}

Our study area lies between $40^{\circ} \mathrm{E}$ and $85^{\circ} \mathrm{E} ; 30^{\circ} \mathrm{S}$ and $65^{\circ} \mathrm{S}$ (Fig. 1) and includes large latitudinal gradients in water masses proprieties with different fronts separating the subtropical waters from the polar waters (Orsi et al., 1995). These fronts are associated with the ACC which is very intense in this area. Some of these fronts depict drastic changes in temperature and salinity (Post et al., 2014; Park et al., 1991, 1993) and delimit large oceanographic regions. The Subtropical Front (STF) defines the southern limit of warm and oligotrophic waters that characterize the subtropical gyre. Further south lies the Sub-Antarctic Front (SAF) associated to the main core of the ACC (Park et al., 2002, 2008), followed by the Antarctic Polar Front (PF). The Sub-Antarctic Zone extends between the STF and the SAF, while the Polar Frontal Zone extends between the SAF and the PF. The Subtropical Zone is located to the north of the STF. In this area, the Sub-Antarctic Zone corresponds to a narrow band of about $2^{\circ}$ of latitude (between $44^{\circ} \mathrm{S}$ and $46^{\circ} \mathrm{S}$ ) that is formed by the convergence of the SAF and STF, in the East of the Kerguelen shelf the PF is also close to the other fronts (Park et al., 1991, 1993). The largest extent of the Polar Frontal Zone is found to the south of Crozet (between $45^{\circ} \mathrm{S}$ and $52^{\circ} \mathrm{S}$ ), while it covers only a few degrees in latitude to the north-east of Kerguelen (Sokolov and Rintoul, 2009). The Subtropical Zone also includes the Agulhas Return Current, current which influences species assemblages in the western subtropical part of the area (Koubbi, 1993). On a longitudinal scale, several shallow island shelves and seamounts diversify the geomorphological landscape and shape the ocean circulation. The Kerguelen plateau is a major bathymetric feature extending from the Kerguelen island shelf towards the Antarctic shelf. It deeply, influences the hydrology of the area. It acts as a barrier deflecting the ACC which flows continuously through the Southern Ocean due to the absence of continental lands (Roquet et al., 2009). The study area is also highly heterogeneous in terms of biological productivity. Most of the ice-free polar waters in the Permanent Open Ocean Zone (zone between $50^{\circ}$ and $60^{\circ} \mathrm{S}$; Pondaven et al., 1998) are characterized by High Nutrient Low Chlorophyll (HNLC; i.e. phytoplankton are not abundant whereas there are high macronutrient levels) conditions due to iron limitation. This trace element limits the primary 


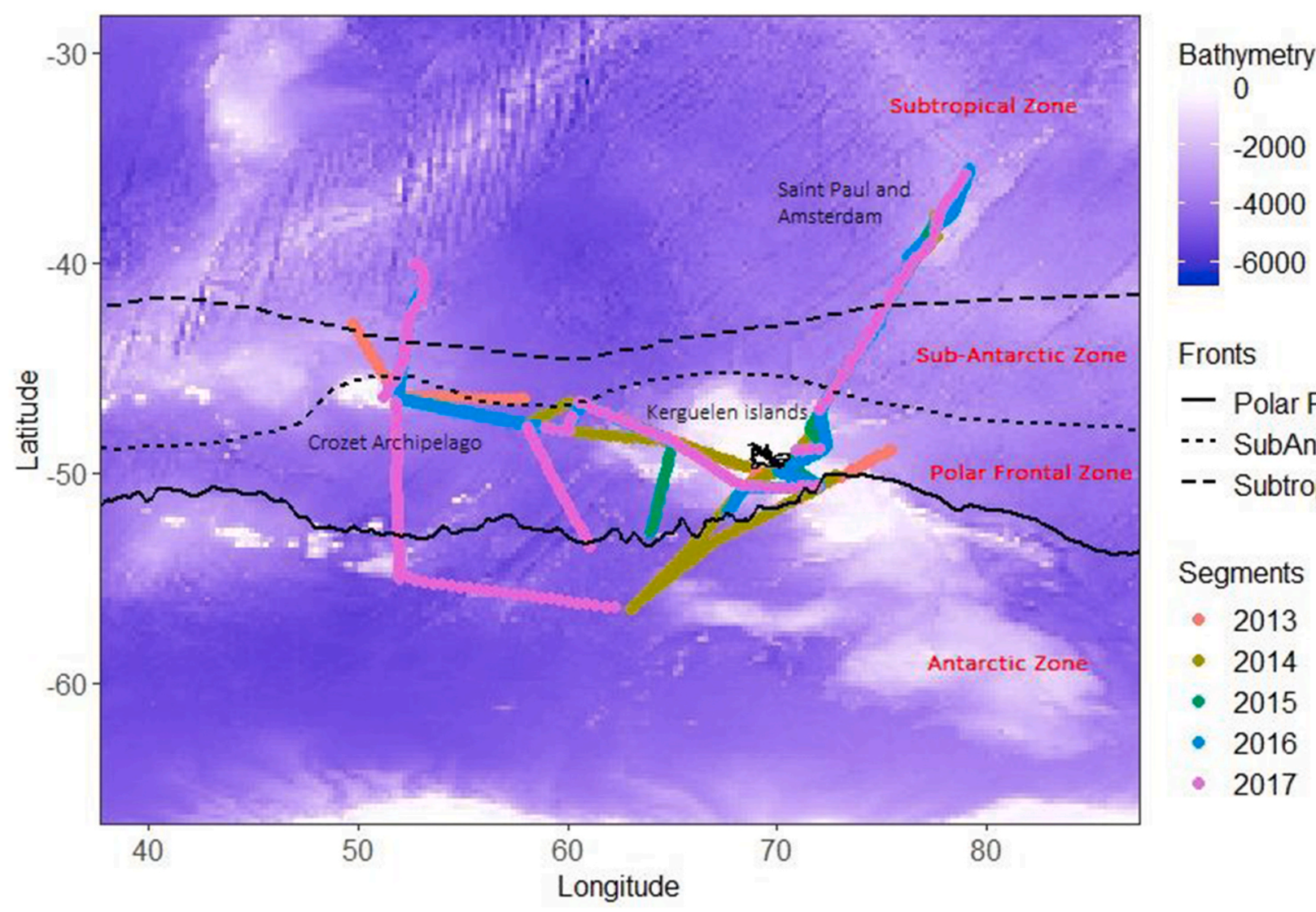

Fig. 1. Map of the study area showing the routes of the oceanographic vessel for each year (2013-2017), the different fronts of the represented area (Subtropical Front, Sub-Antarctic Front and Polar Front) and the different zones of the area (Subtropical Zone, Sub-Antarctic Zone, Polar Frontal Zone and Antarctic Zone). The position of the fronts follows Post et al. (2014).

production in the study area (Martin, 1990; De Baar et al., 2005). The HNLC region contrasts with the intense phytoplankton blooms occurring close to iron sources, notably around the Sub-Antarctic islands. There, the iron is delivered by the interaction of the flow and the shallow topography (Boyd and Ellwood, 2010). This physical and biogeochemical process supports recurrent phytoplankton blooms, occurring during spring over the plateau between Kerguelen and Heard Islands (southeast of Kerguelen), north and east of Kerguelen (Blain et al., 2007; Park et al., 2008), as well as north and east of Crozet (Pollard et al., 2007; Sanial et al., 2014). Conversely, the upstream waters of Kerguelen and Crozet are generally less productive.

\subsubsection{Environmental data}

Our first objective was to delineate bioregions on the basis of four environmental parameters: (i) sea surface temperature, which varies latitudinally in the study area, (ii) chlorophyll- $a$ concentration, which is an indicator of phytoplankton abundance and iron enrichment zones, (iii) kinetic energy, which identifies physically-energetic zones associated with the ACC and (iv) bathymetry, which distinguish shelf from open ocean zones.

Oceanographic data were obtained from satellite measurements from 2013 to 2017 for the period from November to March (i.e. during Austral summer). The parameters studied were sea surface temperature (SST, in ${ }^{\circ} \mathrm{C}$ ), chlorophyll- $a$ concentration (Chl- $a$, in mg.m-3), kinetic energy (KE, in $\mathrm{m}^{2} \cdot \mathrm{s}^{2}$ ) and bathymetry (Bat, in $\mathrm{m}$ ) (Table 1). Each environmental parameter had a different spatial resolution. In order to manage these differences, we carried out bioregionalization at the lowest resolution of the environmental parameters, i.e. the spatial resolution of the kinetic energy at $0.25^{\circ}$.

The KE was calculated from the altimetry-based horizontal current

Table 1

Description of environmental parameters used in this study.

\begin{tabular}{|c|c|c|c|c|}
\hline $\begin{array}{l}\text { Environmental } \\
\text { parameters }\end{array}$ & Abbreviations & Source and products & $\begin{array}{l}\text { Spatial } \\
\text { Resolution }\end{array}$ & $\begin{array}{l}\text { Daily } \\
\text { resolution }\end{array}$ \\
\hline $\begin{array}{l}\text { [Chlorophyll-a] } \\
\text { (mg.m-3) }\end{array}$ & Chl- $a$ & $\begin{array}{l}\text { Copernicus Marine Environmental Monitoring Service website (http://marine.copernicus.eu/): } \\
\text { "OCEANCOLOUR_GLO_CHL_L4_REP_OBSERVATIONS_009_082" for } 2013 \text { and } 2014 \text { data and } \\
\text { "OCEANCOLOUR_GLO_CHL_L4_NRT_OBSERVATIONS_009_033" (satellite products). }\end{array}$ & $0.04^{\circ}$ & $\begin{array}{l}8 \text { days } \\
\text { mean }\end{array}$ \\
\hline $\begin{array}{l}\text { Sea Surface } \\
\text { Temperature }\left({ }^{\circ} \mathbf{C}\right)\end{array}$ & SST & $\begin{array}{l}\text { Copernicus Marine Environmental Monitoring Service website (http://marine.copernicus.eu/): } \\
\text { "SST_GLO_SST_L4_NRT_OBSERVATIONS_010_001" (satellite products). }\end{array}$ & $0.05^{\circ}$ & Daily mean \\
\hline $\begin{array}{l}\text { Kinetic Energy } \\
\left(\mathrm{m}^{2} . \mathrm{s}^{2}\right)\end{array}$ & KE & $\begin{array}{l}\text { KE data were obtained from the zonal and southern velocity (U and V, respectively) which estimate } \\
\text { surface currents derived from altimetry through a geostrophic approximation. U and V are provided in the } \\
\text { 'SEALEVEL_GLO_PHY_L4_REP_OBSERVATIONS_008_047' product which was downloaded from the E.U. } \\
\text { Copernicus Marine Environment Monitoring Service (CMEMS, http://marine.copernicus.eu/for the } \\
\text { period 2013-2017. In this way, an estimation of the total kinetic energy is obtained. }\end{array}$ & $0.25^{\circ}$ & Daily mean \\
\hline Bathymetry (m) & Bat & http://www.gebco.net (satellite products) & $0.008^{\circ}$ & / \\
\hline
\end{tabular}


velocities, using the following formula:

$\mathrm{KE}=0.5^{*}\left(\mathrm{U}^{2}+\mathrm{V}^{2}\right) / 1000$

where $\mathrm{U}$ and $\mathrm{V}$ are the zonal (i.e. longitude) and meridional (i.e latitude) velocities. The bathymetry of the study area was downloaded from the General Bathymetric Chart of the Oceans website (www.gebco.net).

Oceanographic data were downloaded for the period November to March for the years 2013, 2014, 2015, 2016 and 2017. The raw data correspond to daily averages for the SST and KE parameters and weekly averages for the Chl- $a$ parameter, due to the very high cloud cover in the study area. Data were then analyzed using the mean value calculated over the summer period (November to March).

\subsubsection{Zooplankton sampling and identification}

Zooplankton was sampled using a CPR on board the R/V "Marion Dufresne" every summer, between January and February, from 2013 to 2017 , for a total of 1282 samples corresponding to 6410 nautical miles. The CPR is a mechanical device that allows continuous sampling of plankton while being towed in the subsurface behind the vessel (at a speed from 10 to 15 knots). The CPR was towed approximately $100 \mathrm{~m}$ behind the vessel at a depth varying between 10 and $30 \mathrm{~m}$. The CPR works as follows: water enters through a square opening $\left(1.62 \mathrm{~cm}^{2}: 1.27\right.$ $\times 1.27 \mathrm{~cm})$ into a collecting tunnel $(10 \times 5 \mathrm{~cm})$. The plankton then reaches a moving silk band (filter silk) with an average mesh size of 270 $\mu \mathrm{m}$. A second strip of silk (covering silk) covers the filtering silk and is then wound in the fixing tank, which contains diluted formaldehyde. Regardless of the speed of the vessel, the silk advances at a speed of about $1 \mathrm{~cm}$ per nautical mile during towing (Hunt and Hosie, 2003; Hosie et al., 2014).

In the laboratory, each set of silk is unwound and cut by segments of 5 nautical miles. The entire content of each sample is identified at a coarse taxonomic resolution and assigned to one of the following groups: copepods, euphausids, amphipods, Limacina, chaetognaths and ostracods, which are counted under a stereomicroscope. For each major taxon, the individuals are counted in the fraction where at least 100 individuals of that taxon are found. For this a Folsom splitter was used.

Zooplankton abundance data obtained by the CPR (2013-2017) for each taxon and silk sample and the corresponding metadata (GPS coordinates) were stored in a table. The abundances were calculated (number of individuals per nautical mile) and each sample was assigned to the time of day (Day, Dusk, Night, Dawn) which was calculated using the solar angle ("RAtmosphere" package; Biavati, 2014). The number of samples is 552 during the day, 167 at dusk, 338 at night and 225 at dawn.

\subsection{Data processing and statistical analyses}

All statistical analyses were done using R (R Core Team., 2018) and the maps were realized using either $\mathrm{R}$ or using a Geographic Information System (ArcGIS v. 10.5.1.).

\subsubsection{Bioregionalization}

The first step in the bioregionalization procedure was to conduct a principal component analysis (PCA, Legendre and Legendre, package "FactoMineR", 1998; Lê et al., 2008) on environmental parameters (SST, $\mathrm{KE}$, Bat and Chl- $a$ ) to eliminate noise before classification (concentration of information on the first components), resulting in a more stable classification. The second step consisted of clustering sites by applying the method of K-means (MacQueen, 1967) on the coordinates of site on the two first PCA axes. The optimal number of clusters (in this study, the environmental envelopes of bioregions) was chosen using the index of Calinsky and Harabasz, 1974 and the elbow method (Kodinariya and Makwana, 2013). The final step was to create a map of bioregions based on the clusters obtained.

\subsubsection{Characterization of zooplankton sampling}

To study variations in zooplankton abundance (log(abundance +1$)$ ) between the different taxa, a Kruskal-Wallis analysis was conducted. The same analysis was performed without zero values of abundance for each taxon, to take into account the fact that some taxa live in schools in the Southern Ocean. After each Kruskal-Wallis analysis, post-hoc pairwise Wilcoxon rank sum tests were carried out. This consisted of a multiple comparison test with correction by the Holm method (1979) between each pair of taxa to unravel the differences between them.

\subsubsection{Analyses of variation in plankton abundance}

The following analyses were carried out on the total abundance of zooplankton (including data with zero values). To investigate how zooplankton abundance $(\log ($ abundance +1$))$ varied according to the period of the day, a Kruskal-Wallis analysis was performed. The same analysis was performed to test differences in abundances between years. Post-hoc pairwise Wilcoxon rank sum tests were also carried out to unravel the differences between each pair of periods of the day.

These analyses focused on copepods, euphausids and Limacina, which were the most abundant taxa. Night samples were used for this analysis because at night, zooplankton abundance and diversity are higher due to nocturnal migrations. A Kruskal-Wallis test was used to study variations in the abundance of copepods, euphausids and Limacina between the different bioregions. A Kruskal-Wallis test was used to study variations in the abundance of copepods, euphausids and Limacina in the different bioregions. Subsequent post-hoc pairwise Wilcoxon rank sum tests were carried out to reveal the differences between each pair of bioregions regarding the abundance of each taxon. Then, a generalized linear model (with Poisson distribution) was used to study the fluctuations in the abundance of the different taxa as a function of different environmental parameters (SST, the log of KE, the log of Chl- $a$ and the $\log$ of Bat).

\section{Results}

\subsection{Characterization of bioregions}

The first two axes of the PCA on environmental variables explained $70 \%$ of the total variance (Fig. 2). Axis 1 permitted to discriminate sites according to KE and SST while axis 2 permitted to discriminate sites according to Bat and Chl- $a$. The clustering on the first two axes of the PCA on environmental variables identified six distinct bioregions, a number of clusters that allowed us also to describe the study area with sufficient detail to make sense from an ecological point of view (Fig. 2). Indeed, Axis 1 opposes bioregions with relatively high KE and SST (Bioregions 3, 5 and 6) to bioregions with lower KE and SST (Bioregions 4 and 2) and axis 2 further opposes one bioregion with high Chl- $a$ and Bat (Bioregion 1) to the others (Fig. 2). The 6 bioregions are mapped and their environmental variability described in Fig. 3, while Table 2 provides a synthetic overview of their localization and environmental characteristics.

\subsection{Characterization of zooplankton sampling}

The Kruskal-Wallis test showed that the abundance of zooplankton sampled in the surface layer varied significantly between the different taxa (Fig. 4a). Specifically, we found that (i) copepods were more abundant than the other taxa, (ii) the abundance of copepods was not significantly different from the total abundance, (iii) Limacina and amphipod taxa present similar abundances.

In addition, when performing the same analyses without the zero abundance values of the different taxa, we found that the abundance of copepods, euphausids and Limacina differed significantly from each other (Fig. 4b). As the abundance of euphausids and Limacina was significantly higher than the abundance of ostracods, chaetognaths and amphipods (Fig. 4b) and represent the vast majority of the zooplankton 


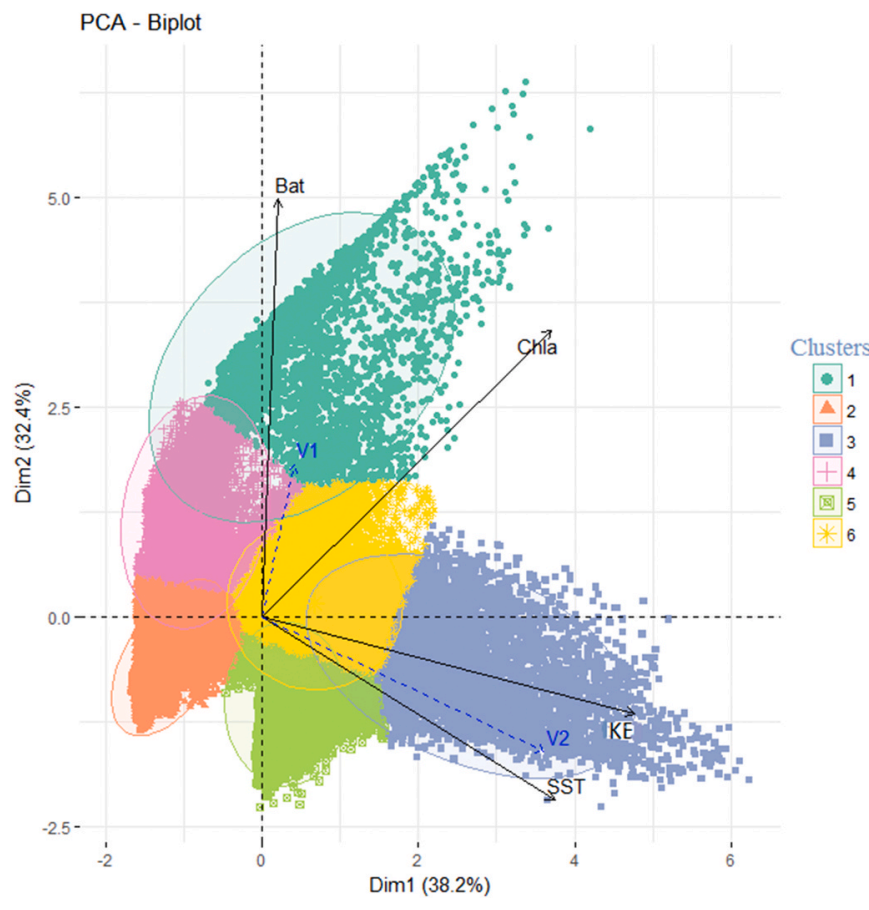

Fig. 2. Principal Component Analysis (PCA) of environmental parameters (SST: Sea Surface Temperature $\left({ }^{\circ} \mathrm{C}\right)$; KE: Kinetic Energy $\left(\mathrm{m}^{2} . \mathrm{s}^{2}\right)$; Chl-a: concentration of Chlorophyll-a (mg.m-3) and Bat: Bathymetry (m)) on the two first significant axes of the PCA (Dim1, Dim2)). V1 = longitude and V2 = latitude are supplementary variables that do not influence the PCA. The colour of the 6 clusters is represented on the observations and concentration ellipses. (For interpretation of the references to colour in this figure legend, the reader is referred to the Web version of this article.)

sampled, we decided to focus the following statistical analyses only on copepods, euphausids and Limacina.

\subsection{Temporal variations in zooplankton abundance}

Kruskal-Wallis analyses and the post-hoc tests of Wilcoxon generally showed that the abundance of zooplankton sampled in the surface layer was significantly higher at night and lower during the day (Fig. 5a). Kruskal-Wallis analyses showed that the abundance of zooplankton sampled in the surface layer did not vary significantly from year to year (Fig. 5b).

\subsection{Variations in zooplankton abundances across bioregions}

The copepod, Limacina and total night abundances did not differ significantly between Bioregions 1 to 5 (Fig. 6). Nonetheless, copepod, Limacina and total night abundances were the lowest in Bioregion 6, with significant differences with Bioregions 1, 2, and 4 depending on the group (Fig. 6). Euphausid abundance did not differ significantly among Bioregions 1 and 3 to 6 , but was significantly lower in Bioregion 2 than in Bioregions 1 and 6 (Fig. 6).

The bioregions identified in the cluster analysis are differently represented by the zooplankton samples. In particular, Bioregion 3 and Bioregion 5 are largely under-sampled with respectively 3 and 11 samples collected within the five campaigns. This may explain why the zooplankton abundance found there did not differ significantly from any bioregion (Fig. 6).

\subsection{Variations in zooplankton abundance with environmental parameters}

The first GLM model showed that the night abundance of copepods was significantly related to mean SST and KE. Specifically, the
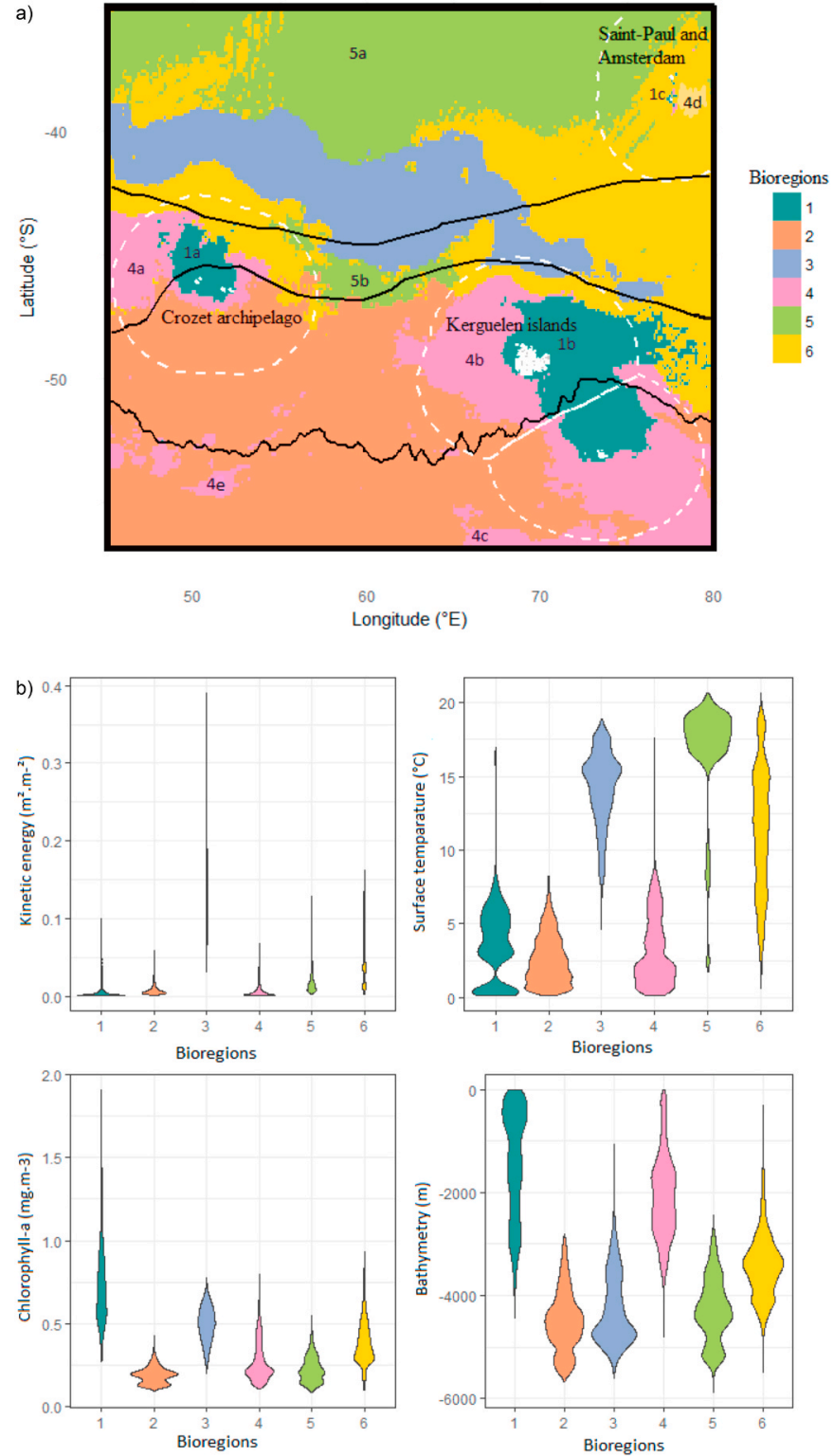

Fig. 3. Bioregions defined by SST, KE, Chl-a and Bat (SST: Sea Surface Temperature; KE: Kinetic Energy; Chl-a: concentration of Chlorophyll-a and Bat: Bathymetry). Map of the six bioregions and position of the 3 main hydrological fronts (from north to south: STF, SAF and PF), the white dashed lines correspond to the exclusive economic zones (a). Violin plots of environmental parameters (SST, KE, Chl-a and Bat) according to the six bioregions (b).

abundance of copepods decreased as the mean SST increase, whereas it slightly increased as the mean KE increased (Fig. 7).

The second GLM model showed that the night abundance of euphausids was significantly related to the mean Chl- $a$ concentration. Specifically, the abundance of euphausids increased as the mean Chl- $a$ increased (Fig. 7).

The third GLM model showed that the night abundance of Limacina was significantly related to mean Chl- $a$ and Bat. Specifically, the abundance of Limacina increased as the mean Chl- $a$ increased and decreased as the mean Bat increased (Fig. 7).

\section{Discussion}

In this study, we provided a new set of epipelagic bioregions for the South Indian Ocean and the Indian part of the Southern Ocean at macroand meso-scale according to their environmental characteristics. 
Table 2

Descriptions of the six bioregions identified in the study area and shown in Figs. 2 and 3.

\begin{tabular}{|c|c|c|}
\hline Bioregions & Localization & Characteristics \\
\hline 1 & Shelf and high productivity off-shelf waters & $\begin{array}{l}\text { - Cold SST }\left(\min =0.11{ }^{\circ} \mathrm{C} \text {, mean }=3.57{ }^{\circ} \mathrm{C}, \max =16.96{ }^{\circ} \mathrm{C}\right) \\
\text { - Low } \mathrm{KE}\left(\min =0.00 \mathrm{~m}^{2} . \mathrm{s}^{2}, \text { mean }=0.00 \mathrm{~m}^{2} . \mathrm{s}^{2}, \max =0.09 \mathrm{~m}^{2} . \mathrm{s}^{2}\right) \\
\text { - High Chl- } a\left(\min =0.27 \mathrm{mg} \cdot \mathrm{m}^{-} 3, \text { mean }=0.73 \mathrm{mg} \cdot \mathrm{m}^{-3}, \max =1.91 \mathrm{mg} \cdot \mathrm{m}^{-3}\right) \\
\text { - Shallow sea }(\min =-4443.0 \mathrm{~m}, \text { mean }=-1434.7 \mathrm{~m}, \max =-2.0 \mathrm{~m})\end{array}$ \\
\hline 2 & Deep Eastern Part of the Enderby basin & $\begin{array}{l}\text { - Cold SST }\left(\min =0.19{ }^{\circ} \mathrm{C}, \text { mean }=2.59{ }^{\circ} \mathrm{C}, \max =8.21{ }^{\circ} \mathrm{C}\right) \\
\text { - Low KE }\left(\min =0,00 \mathrm{~m}^{2} . \mathrm{s}^{2}, \text { mean }=0.01 \mathrm{~m}^{2} \cdot \mathrm{s}^{2}, \max =0.05 \mathrm{~m}^{2} . \mathrm{s}^{2}\right) \\
\text { - Low Chl- } a\left(\min =0.09 \mathrm{mg} \cdot \mathrm{m}^{-} 3, \text { mean }=0.19 \mathrm{mg} \cdot \mathrm{m}^{-} 3, \max =0.42 \mathrm{mg} \cdot \mathrm{m}^{-3}\right) \\
\text { - Deep sea }(\min =-5680 \mathrm{~m}, \text { mean }=-4499 \mathrm{~m}, \max =-2801 \mathrm{~m})\end{array}$ \\
\hline 3 & High turbulence areas of SAF and SFT & 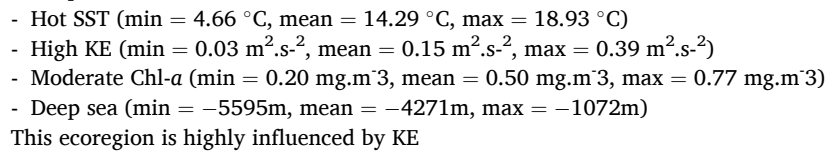 \\
\hline 4 & Island shelves less productive areas and seamounts & $\begin{array}{l}\text { - Cold SST }\left(\min =0.18{ }^{\circ} \mathrm{C}, \text { mean }=3.16{ }^{\circ} \mathrm{C}, \max =17.62{ }^{\circ} \mathrm{C}\right) \\
\text { - Low KE }\left(\min =0.00 \mathrm{~m}^{2} \cdot \mathrm{s}^{2}, \text { mean }=0.01 \mathrm{~m}^{2} \cdot \mathrm{s}^{2}, \max =0.06 \mathrm{~m}^{2} \cdot \mathrm{s}^{2}\right) \\
\text { - Low Chll- } a\left(\min =0.10 \mathrm{mg} \cdot \mathrm{m}^{-} 3, \text { mean }=0.26 \mathrm{mg} \cdot \mathrm{m}-3, \max =0.80 \mathrm{mg} \cdot \mathrm{m}^{-} 3\right) \\
\text { - Shallow sea }(\min =-4791 \mathrm{~m}, \text { mean }=-2087 \mathrm{~m}, \max =-13 \mathrm{~m})\end{array}$ \\
\hline 5 & Indian Ocean Deep & $\begin{array}{l}\text { - High SST }\left(\min =1.74{ }^{\circ} \mathrm{C}, \text { mean }=17.01{ }^{\circ} \mathrm{C}, \max =20.69{ }^{\circ} \mathrm{C}\right) \\
\text { - Low KE }\left(\min =0.00 \mathrm{~m}^{2} . \mathrm{s}^{2}, \text { mean }=0.02 \mathrm{~m}^{2} . \mathrm{s}^{2}, \max =0.12 \mathrm{~m}^{2} . \mathrm{s}^{2}\right) \\
\text { - Low Chl- } a\left(\min =0.08 \mathrm{mg} \cdot \mathrm{m}-3, \text { mean }=0.22 \mathrm{mg} \cdot \mathrm{m}^{-3}, \max =0.55 \mathrm{mg} \cdot \mathrm{m}-3\right) \\
\text { - Deep sea }(\min =-5887 \mathrm{~m}, \text { mean }=-4283 \mathrm{~m}, \max =-2437 \mathrm{~m})\end{array}$ \\
\hline 6 & Indian ridges subtropical & $\begin{array}{l}\text { - High SST }\left(\min =0.62{ }^{\circ} \mathrm{C}, \text { mean }=7.98{ }^{\circ} \mathrm{C}, \max =20.69{ }^{\circ} \mathrm{C}\right) \\
\text { - Low KE }\left(\min =0.00 \mathrm{~m}^{2} . \mathrm{s}^{2}, \text { mean }=0.05 \mathrm{~m}^{2} . \mathrm{s}^{2}, \max =0.16 \mathrm{~m}^{2} . \mathrm{s}^{-2}\right) \\
\text { - Low Chl- } a\left(\min =0.10 \mathrm{mg} \cdot \mathrm{m}^{-} 3, \text { mean }=0.38 \mathrm{mg} \cdot \mathrm{m}^{-} 3, \max =0.93 \mathrm{mg} \cdot \mathrm{m}^{-} 3\right) \\
\text { - Deep sea }(\min =-5497 \mathrm{~m}, \text { mean }=-3433 \mathrm{~m}, \max =-319 \mathrm{~m})\end{array}$ \\
\hline
\end{tabular}

Furthermore, we highlighted how the abundance of the different zooplankton taxa varied spatially with environmental conditions.

\subsection{Bioregionalization of the Indian part of the Southern Ocean and adjacent South Indian Ocean}

The six bioregions were determined according to three physical environmental parameters (sea surface temperature, kinetic energy, bathymetry) and chlorophyll- $a$ concentration which is considered as a proxy of the surface primary production. These bioregions provide a synthetic and integrated overview of contrasting environments characterized by different biophysical processes (Table 2). In accordance with previous studies by Grant et al. (2006) and Raymond (2014), the six bioregions we identified follow a latitudinal pattern. However, our study included the Southern part of the Indian Ocean (Bioregions 3, 5 and 6 and the islands of Saint Paul and Amsterdam) in addition to the Southern Ocean (Bioregions 1, 2 and 4). Therefore, this study provides details about the transition between these two oceans which are separated by different major fronts, mainly the Sub-Antarctic and the Subtropical Fronts. The main characteristics of the six bioregions are described below.

Bioregion 1 is mainly located to the east of the Kerguelen Plateau and north of the Heard Plateau, on the central and northern part of the Crozet Plateau and in a small extent, around the St. Paul Islands and the New Amsterdam Plateau. This region corresponds to areas with high chlorophyll- $a$ concentrations (Fig. 3). Indeed, the distribution of chlorophyll- $a$ in the Southern Ocean is dominated by a number of recurrent blooms observed downstream of islands (Sokolov and Rintoul, 2007). These blooms are sustained by the iron enrichment of water masses from the Sub-Antarctic Islands and their plateaus (Blain et al., 2001; Sanial et al., 2014; Graham et al., 2015; d'Ovidio et al., 2015).

Bioregion 2 is located in the deep eastern part of the Enderby Basin in the Southern Ocean, south of SAF. The kinetic energy is low, as well as the sea surface temperature and chlorophyll- $a$ concentration, thus representing a typical HNLC zone. South of Crozet, the PF at about $50^{\circ} \mathrm{S}$ has a low current velocity (Park et al., 1993; Pollard and Read, 2001; Pollard et al., 2002, 2007). The low chlorophyll- $a$ concentrations are a consequence of iron deficiency (Boyd et al., 2000, 2007; Pollard et al., 2007; De Baar et al., 2005). Indeed, this area is very deep and remote from islands, shallow plateaus or seamounts (which are the main source of iron in the region) (e.g. Ardyna et al., 2017).

Bioregion 3 corresponds to the physically-energetic areas of the Indian Ocean characterized by high kinetic energy (Fig. 3). The ACC flows mainly to the north of the Crozet and Kerguelen plateau, the latter being a major obstacle to the eastward flow of the ACC (Roquet et al., 2009). High kinetic energies in this region indicate intense horizontal velocities generated by the ACC and the Agulhas Current. After Bioregion 1, Bioregion 3 is the area with the higher chlorophyll- $a$ concentration. Indeed, the intense horizontal velocities allow the transport of nutrient from the shallow topographies around the African coasts into the open ocean for thousands of kilometers sustaining the phytoplankton productivity (e.g. Ardyna et al., 2017). In addition, this area is characterized by an intense mesoscale activity associate to meanders, eddies, filaments and fronts which may also enhance the primary production (e.g. Flierl and Davis, 1993; Oschlies and Garçon, 1998; Machu and Garçon, 2001; Lévy, 2008).

Bioregion 4 is characterized by shallow to mid bathymetry and low chlorophyll- $a$ concentrations and is located either in the deepest parts of the island shelves, mainly in the western part of these shelves, and over complex seamounts (Figs. 2 and 3). The relative low chlorophyll- $a$ concentration in the western part of the shelf areas (Fig. 3b) may be explained by the zonal location of this bioregion relatively to the plateau. Indeed, due to the main eastward circulation of the ACC, the iron enrichment of the water masses is more intense in the eastern part of the shelves and offshore, generating a longitudinal chlorophyll- $a$ gradient upstream and downstream of the plateau (e.g Sanial et al., 2014; d'Ovidio et al., 2015). This difference can be observed with contrasted chlorophyll- $a$ concentrations between Bioregion 4 (western flank, lower chlorophyll- $a$ concentration) and Bioregion 1 (eastern flank, higher chlorophyll- $a$ concentration). The relative shallow depth of the areas of the Bioregion 4 which are located offshore from the islands is explained by the numerous seamounts included in these areas. These are the large Skif bank to the south-west of Kerguelen and the Elan Bank south-west of Heard at the limit of the study area (Bioregion $4 \mathrm{~b}$ in Fig. 3). South of Crozet, different seamounts of smaller size such as Ob, Lena and Marion Dufresne are located near the PF (Bioregion 4e in Fig. 3). The presence of shallow seamounts may also stimulate the nutrient input in the euphotic layer thus sustaining higher chlorophyll- $a$ concentrations compared to the surrounding water of the abyssal plain (Bioregion 2) (e.g. Pitcher et al., 2008). 

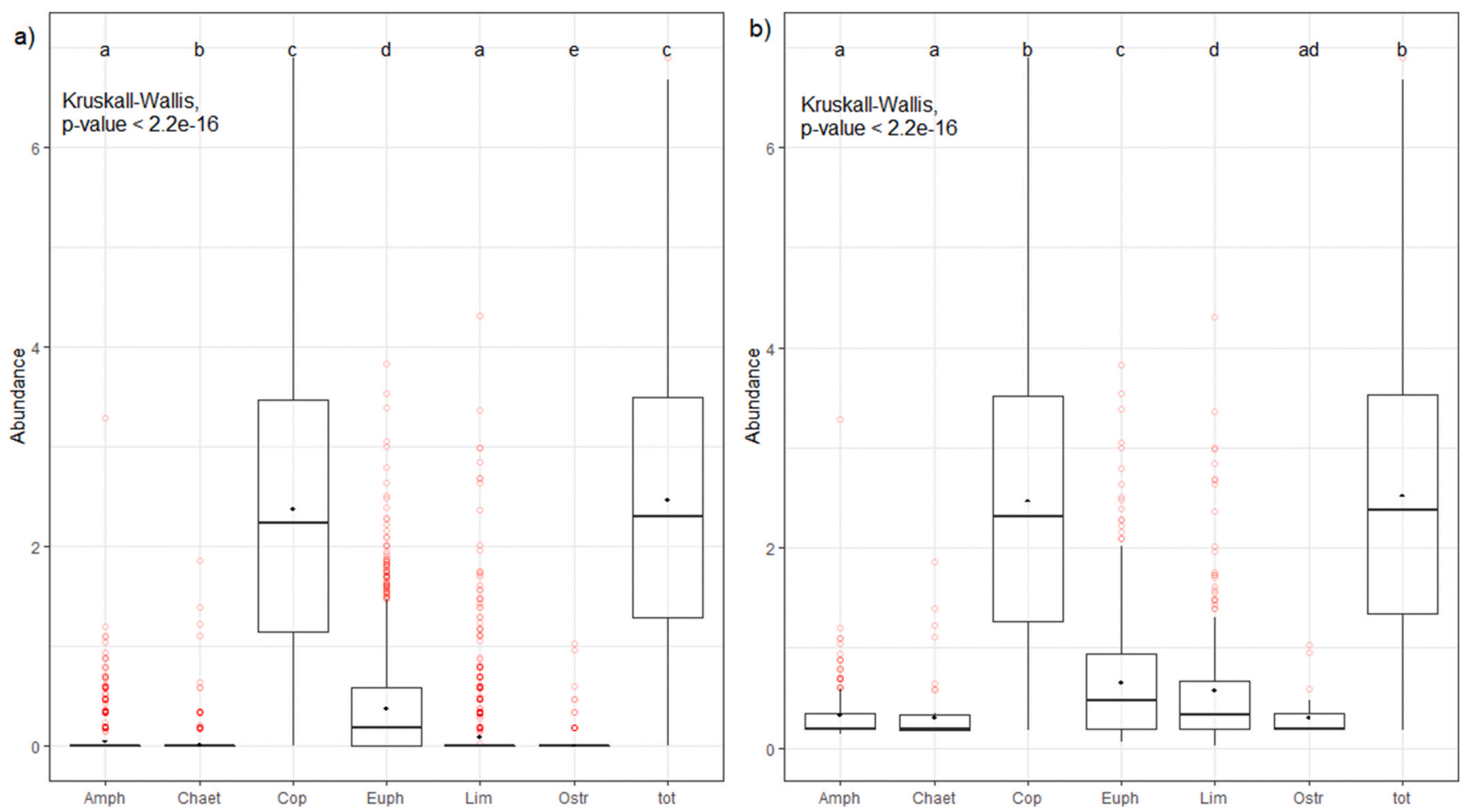

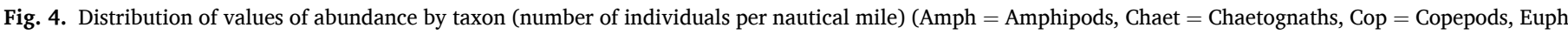

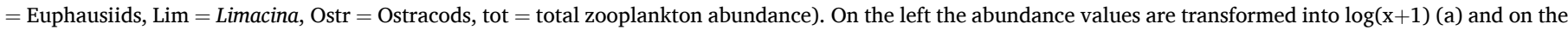

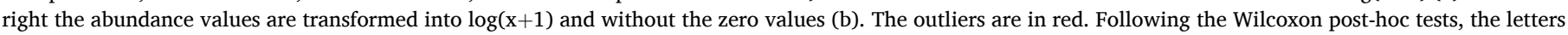

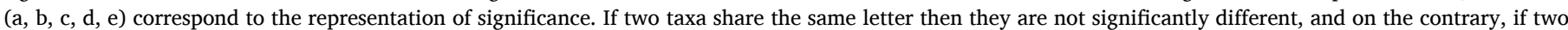

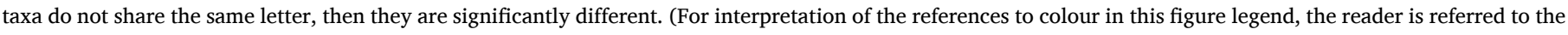
Web version of this article.)

Bioregion 5 is located in the Subtropical Indian Ocean (5a) and to the north of the STF (5b), two areas of abyssal plains or hills (Harris et al., 2014). They are characterized by higher temperatures and represent the deepest zones of the Indian Ocean. Bioregion $5 \mathrm{a}$ is the warmest region and Bioregion 5b is the deepest region (Fig. 3) (Harris et al., 2014). The low chlorophyll- $a$ concentrations found in Bioregion 5 are typical of the hyperoligotrophic waters of the subtropical gyres (e.g. McClain et al., 2004; Morel et al., 2010).

Bioregion 6 is characterized by a large thermal amplitude and can be considered as an Indian Subtropical region with deep bathymetry and low kinetic energy. This area also includes shallower seamounts at the mid-ocean ridges (Harris et al., 2014). This area is divided into two sub-areas by Bioregion 3. However, the main part is located to the northeast of the study area, around the St Paul and Amsterdam Islands, and includes part of the Southeast Indian Ridge. The northwestern part includes part of the Southwest Indian Ridge in Indian Ocean.

\subsection{Spatial variations in zooplankton abundance}

Consistent with previous CPR studies conducted in various regions of the Southern Ocean, we found that copepods account for most of the zooplankton biomass (Hunt and Hosie, 2003, 2006a, 2006b; Hosie et al., 2003; Takahashi et al., 2002, 2010, 2011). Our analyses of copepods, euphausids and Limacina sampled at night permitted to reveal the spatial patterns in the abundance of the different taxa across our study area encompassing the Southern Ocean and the South Indian Ocean. These spatial patterns are explained by (i) the high dependence of copepod abundance on sea surface temperature and, to a lesser extent, kinetic energy; (ii) the high dependence of euphausid abundance on chlorophyll-a concentration; (iii) the high dependence of Limacina abundance on chlorophyll- $a$ concentration and shallow bathymetry.
The GLM models indicate that the copepods were most abundant in the cold waters of the Southern Ocean. Accordingly, the abundance of copepods was significantly highest in Bioregions 1, 2 and 4, which are located in the southern part of the study area and correspond to the coldest zones in the Permanent Open Ocean Zones, than in Bioregion 6. This is because temperature has major effects on the physiology of zooplankton in Antarctic and is therefore one of the main factors defining its biogeographic distributions (Pörtner et al., 2007). Furthermore, the GLM models revealed a greater abundance of copepods in physically-energetic waters. Although copepods are quite abundant in Bioregion 3, i.e. the most physically-energetic zone of our study area located in the Subtropical and Sub-Antarctic regions, their abundance in this under-sampled bioregion does not differ significantly from the others. Further in situ analysis of zooplankton abundance in this high turbulent region could allow us testing this relationship within pelagic bioregions.

The GLM models also revealed that euphausids were more abundant in chlorophyll- $a$ rich areas. Specifically, they were significantly less abundant in low productive open ocean waters of Bioregion 2 compared to the shelf and off-shelf high productivity areas of Bioregion 1 . The higher abundance of euphausids in the Indian ridges subtropical waters of Bioregion 6 could also be related to the higher chlorophyll- $a$ found there. This positive relationship between the abundance of euphausids and chlorophyll- $a$ is not surprising because primary production corresponds to phytoplankton, the main food of zooplankton. This further supports previous studies showing that zooplankton biomass is globally found to be positively related to the phytoplankton biomass (Irigoien et al., 2004).

The GLM models also identify a positive relationship between Limacina abundance and chlorophyll- $a$, and a positive relationship of Limacina abundance with bathymetry. Consequently, the higher 

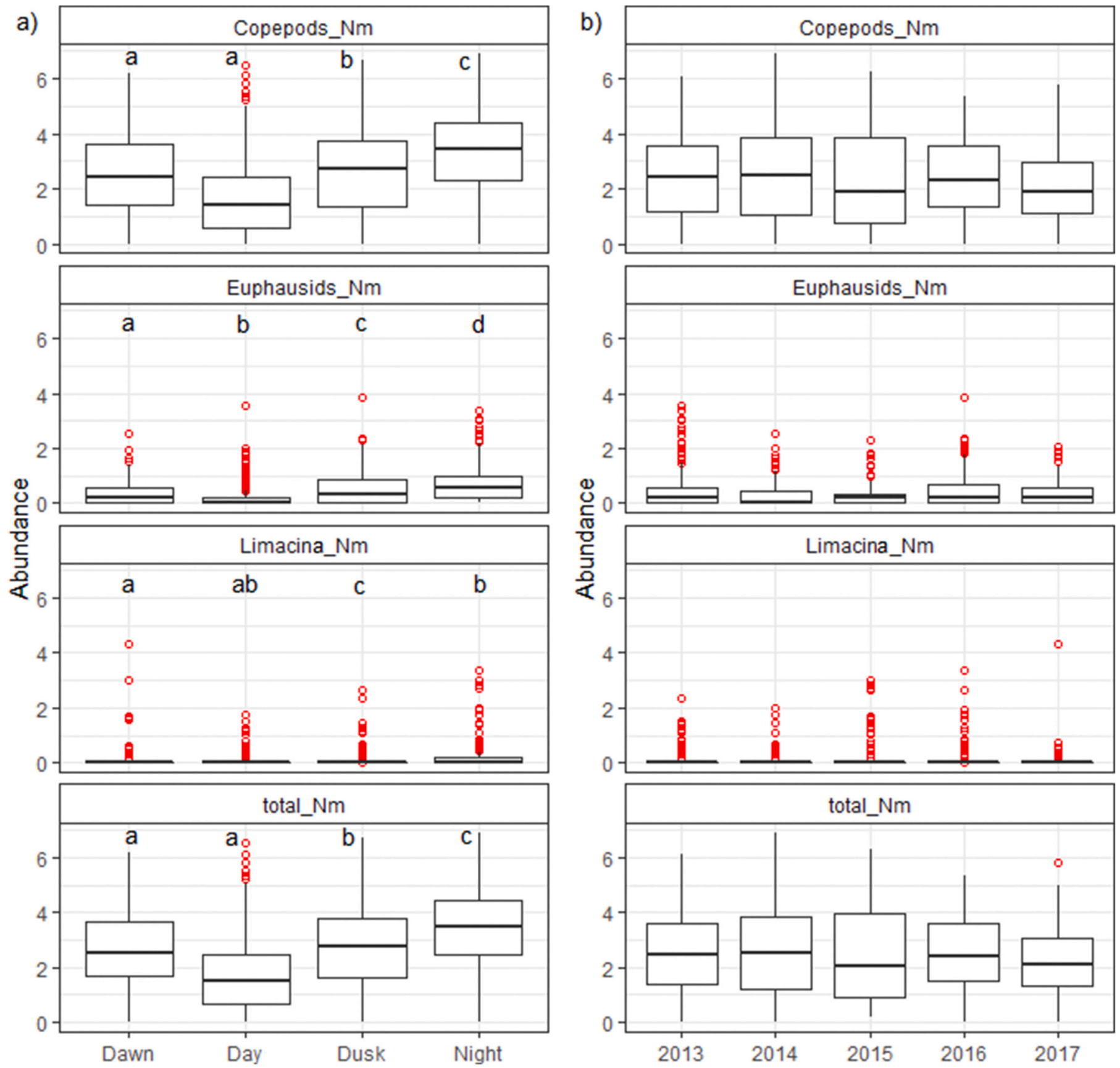

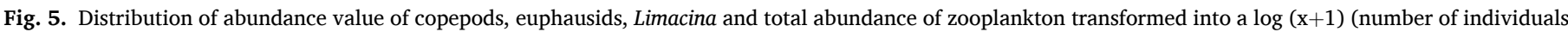

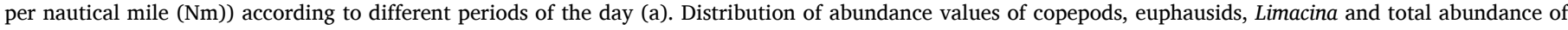

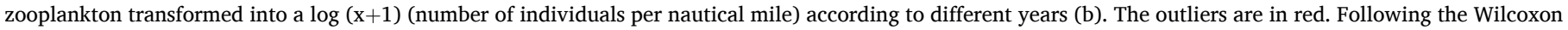

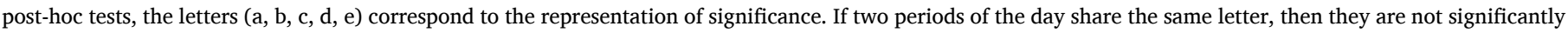

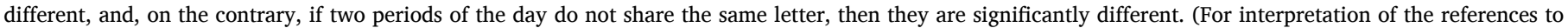
colour in this figure legend, the reader is referred to the Web version of this article.) 

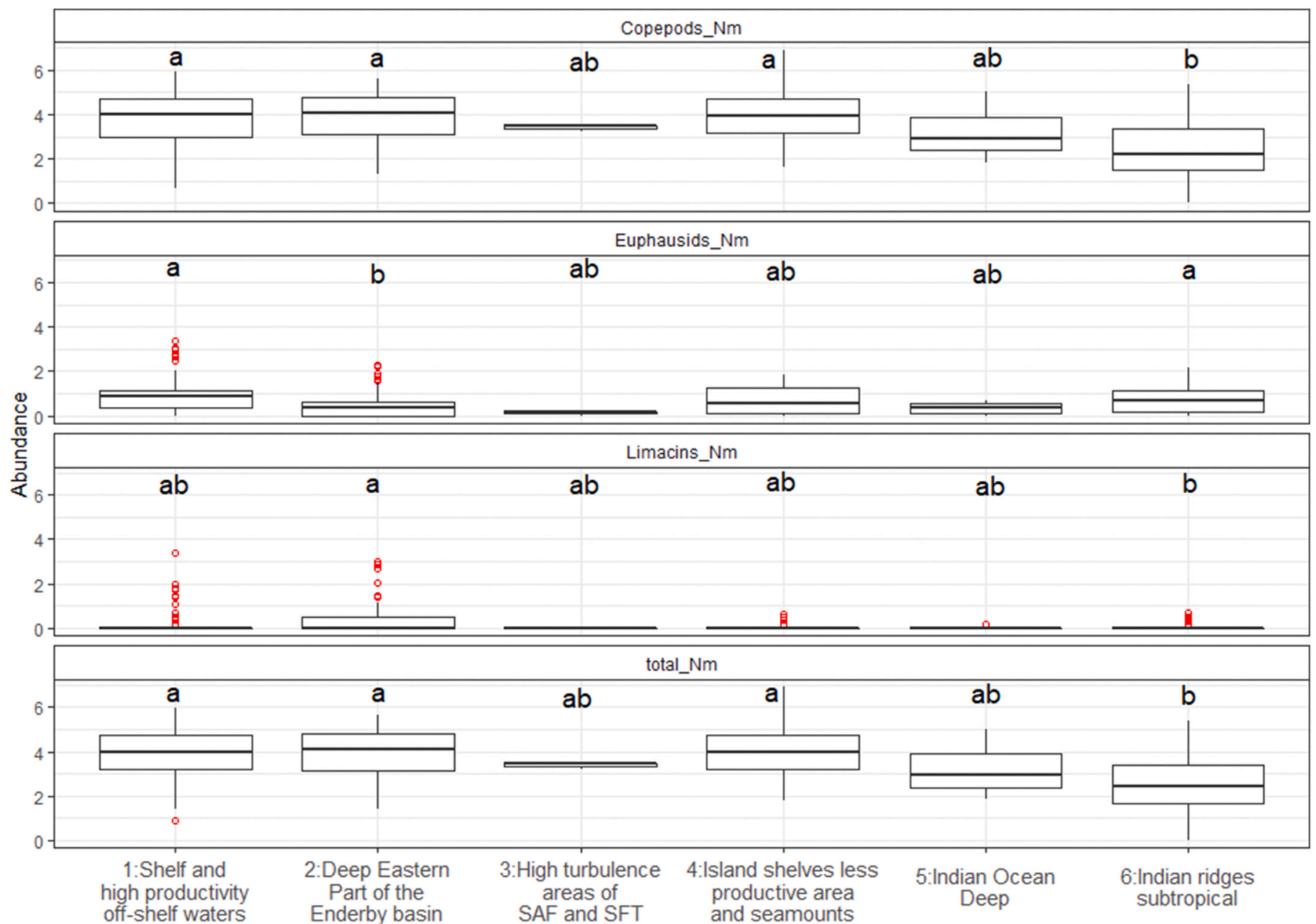

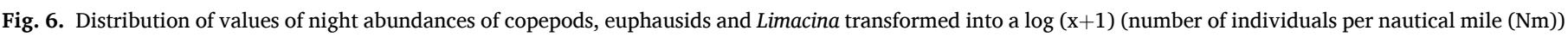

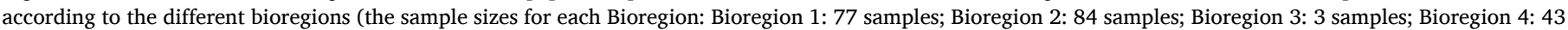

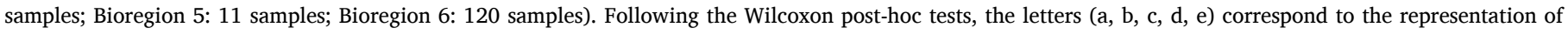

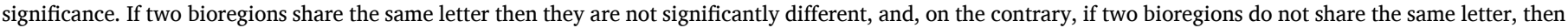
they are significantly different.

abundance of Limacina in Bioregion 2 could be related to the more important depths found there. Although not significantly, the shallow shelves of Bioregion 1 also display lower Limacina abundance. Further investigations should be done in order to confirm the relationship between Limacina abundance and shallow topographies, poorly covered by the existing literature.

Overall, although there are correlations between the three groups of zooplankton and environmental conditions, the different zooplankton groups do not map very well onto the bioregions. Several causes could explain this. Firstly, some key transition bioregions essential for understanding the variability of the studied region - such as Bioregion 3, the high turbulent area between the SAF and the STF - have been undersampled. Secondly, the coarse taxonomic resolution used in this study could have hampered the identification of clear differences between bioregions. As suggested by previous studies, and given the large temperature gradient sampled, species level data would likely better reveal differences between bioregions in our study area (e.g. Hunt et al., 2011).

\subsection{Limits and perspectives}

The environmental parameters used in this study come from satellite observations averaged over time and space. Due to their large spatial coverage, these data can be used to distinguish spatial environmental variations between areas in two dimensions (latitude and longitude) and to explain surface variation in zooplankton abundance. However, these measurements do not take into account how environmental conditions and zooplankton abundance vary according to the vertical dimension, i. e. the depth of the zone. The environmental properties of the water column can influence the ecology of many species along the trophic webs, including top predators (Bost et al., 2009). In addition, we did not consider all the environmental parameters that can affect the abundance of zooplankton. Future studies may consider delineating bioregions in three dimensions and integrating other potentially harmful environmental parameters for zooplankton (e.g. ocean acidification, UV or nutrient levels) to better anticipate the impact of environmental changes on zooplankton in each bioregion.

\subsection{Conclusion}

In this study, we first characterized bioregions based on physical parameters and chlorophyll- $a$. We then investigated the variations in zooplankton abundance across these bioregions in order to move from a bioregionalization procedure towards an ecoregionalization procedure by progressively integrating species assemblages. Initially, the temporal variations in surface abundance are explained by nocturnal migrations, i.e. zooplankton is more abundant at night in the surface layer. The 

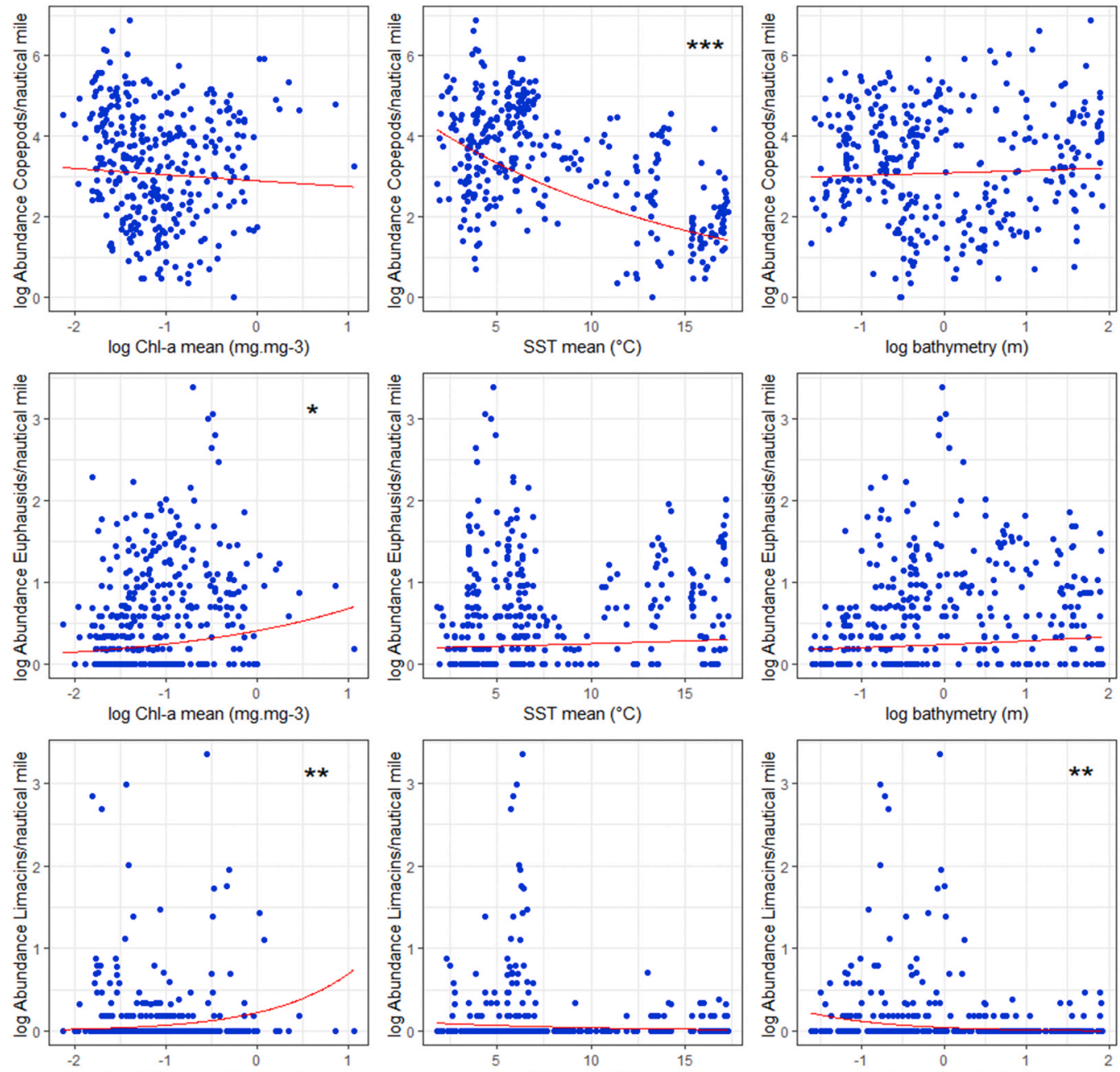

$\log$ Chl-a mean (mg.mg-3)

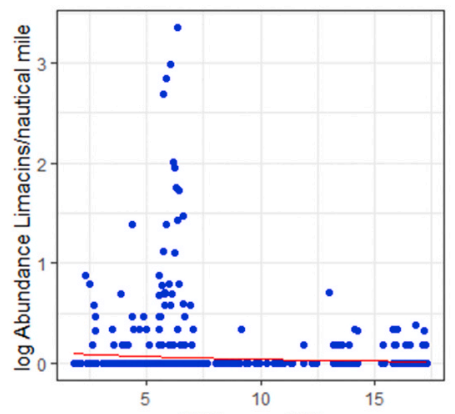

SST mean $\left({ }^{\circ} \mathrm{C}\right)$
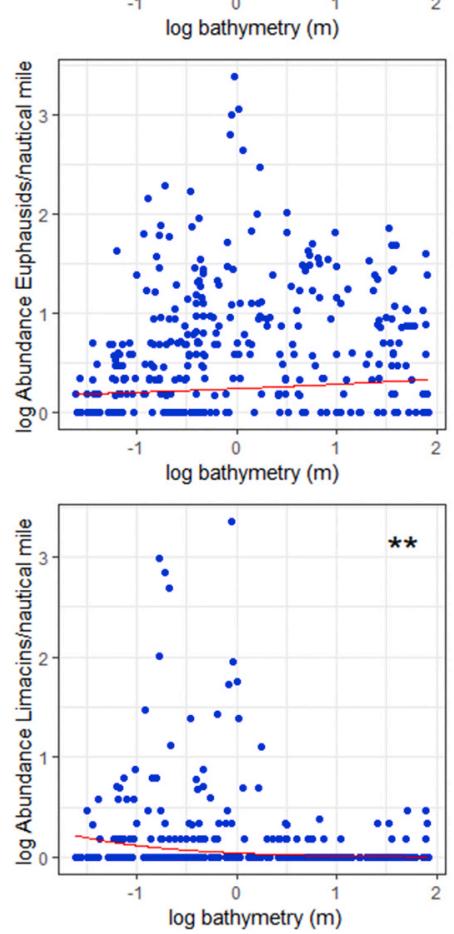
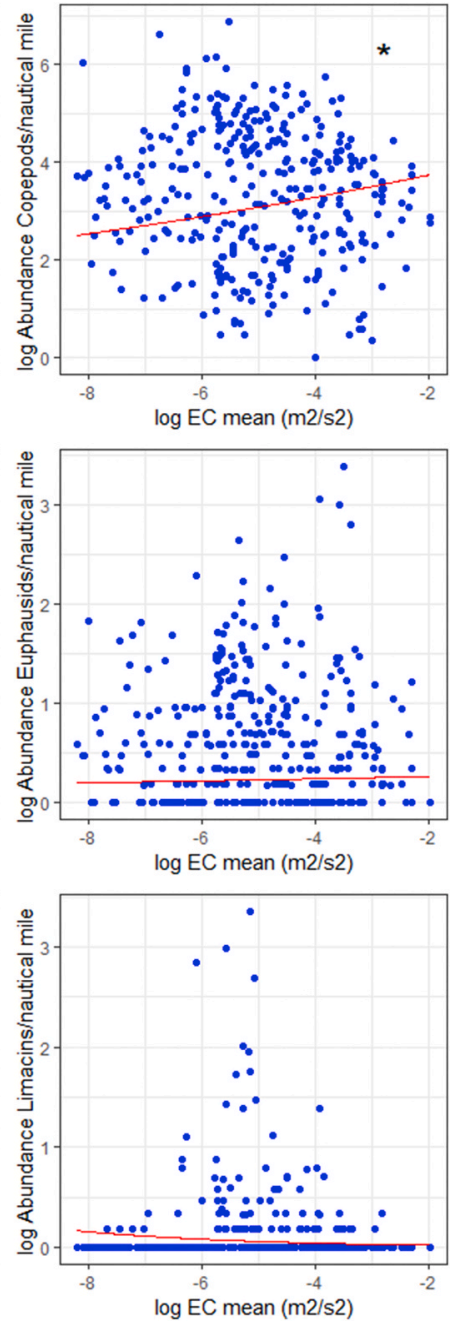

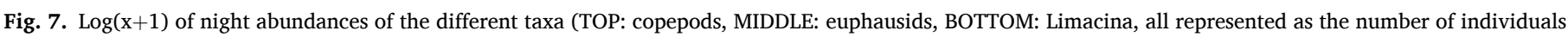

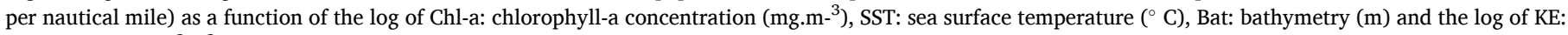
kinetic energy $\left(\mathrm{m}^{2} \cdot \mathrm{s}^{2}\right){ }^{*}=\mathrm{p}<0.05, * *=\mathrm{p}<0.01,{ }^{* * *}=\mathrm{p}<0.001$ (GLM).

variations in zooplankton abundance are also explained spatially by environmental parameters and, to a lesser degree, by the bioregions. Future campaigns in the under-sampled transition bioregions are needed to determine whether the observed variations could be explained more consistently by the bioregionalization at the meso- and macro-scale, or whether other spatial scales should be considered for their representation.

This study complements previous ecoregionalization work (Koubbi et al., 2016a, 2016b) carried out at smaller spatial scales in the ocean zone around Kerguelen and/or Crozet on the pelagic realm, including seabirds and marine mammals. This work is therefore a further step towards the identification of coherent ecoregions. Once constructed and characterized, these ecoregions will serve as a basis for optimizing marine biodiversity conservation strategies in this part of the Southern Ocean where marine reserves around Crozet, Kerguelen and St-Paul/New Amsterdam where declared by France in 2016 (Koubbi et al., 2016a, 2016b).

An important step forward in ecoregionalization would be the integration of all species in the food web - from phytoplankton to zooplankton, fish and top predators. Indeed, as the different trophic groups do not respond in the same way to spatiotemporal variations in their environment (Koubbi et al., 2011), the way forward to an ecoregionalization of this area is to identify indicator or assemblages from distinct trophic levels. Future work should therefore investigate further regionalization of less studied mesopelagic fish. Then, it would be interesting to integrate the regionalizations of the different trophic levels in order to obtain a comprehensive regionalization.

\section{Declaration of competing interest}

None to declare.

\section{Acknowledgements}

This work was supported by IPEV, the Flotte Océanographique Française, Zone Atelier Antarctique - CNRS, the European H2020 International Cooperation project MESOPP [grant number 692173] and the TAAF (Southern Lands and Antarctic French Territories) natural reserve. It is related to the SCAR Southern Ocean CPR programme and the Global Alliance CPR Surveys We thank the IPEV teams who were in charge of logistics during the oceanographic surveys, as well as the crew members of the R/V "Marion Dufresne". We warmly thank Chloé Mignard and Baptiste Sérandour for participating in processing and identification of samples, and Patrice Pruvost for taking in charge the zooplankton sampling during the 2016 survey. 


\section{Appendix A}

Outputs of the elbow method (A) and the method of the Calinski Harabasz index (B) which were used was used to choose the optimal number of clusters and determined the 6 bioregions of our study.

(A)

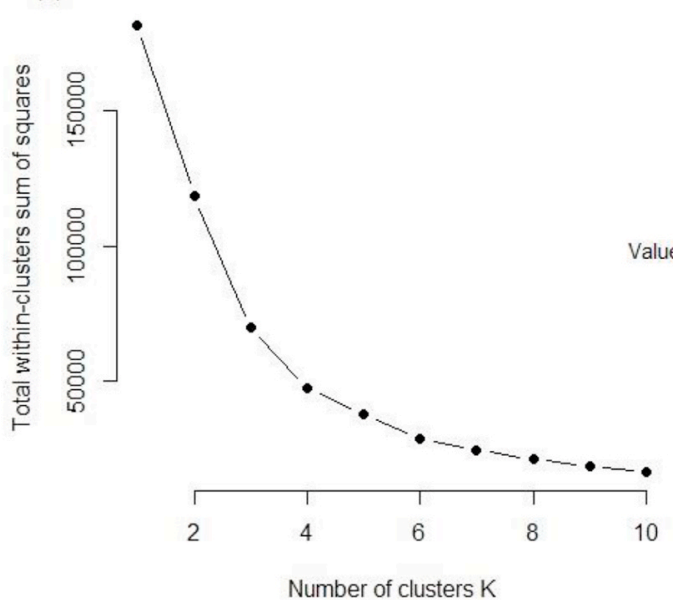

(B)

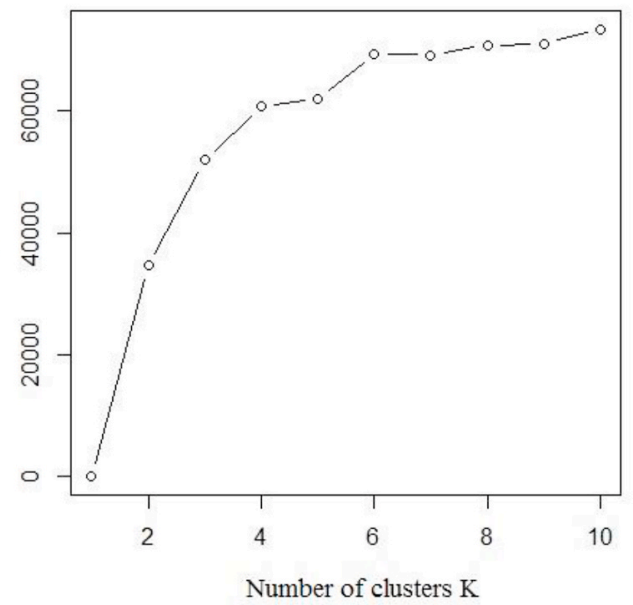

\section{References}

Ainley, D.G., Ballard, G., Weller, J., 2010. Ross Sea bioregionalization, part I: validation of the 2007 CCAMLR bioregionalization workshop results towards including the Ross Sea in a representative network of marine protected areas in the Southern Ocean. CCAMLR. Document WG-EMM-10/11.

Ardyna, M., Claustre, H., Sallée, J.B., D’Ovidio, F., Gentili, B., Van Dijken, G., et al., 2017. Delineating environmental control of phytoplankton biomass and phenology in the Southern Ocean. Geophys. Res. Lett. 44 (10), 5016-5024. https://doi.org/ 10.1002/2016GL072428.

Batten, S.D., Abu-Alhaija, R., Chiba, S., Edwards, M., Graham, G., Jiyothibabu, R., et al. 2019. A global plankton diversity monitoring program. Front. Mar. Sci. 6, 321.

Béhagle, N., Cotté, C., Ryan, T.E., 2016. Acoustic micronektonic distribution is structured by macroscale oceanographic processes across $20-50^{\circ} \mathrm{S}$ latitudes in the SouthWestern Indian Ocean. Deep-Sea Res. Part I Oceanogr. Res. Pap. 110, 20-32. https:// doi.org/10.1016/j.dsr.2015.12.007.

Biavati, G., 2014. RAtmosphere: standard Atmospheric profiles. Retrieved from. http s://cran.r-project.org/package=RAtmosphere.

Blain, S., Tréguer, P., Belviso, S., Bucciarelli, E., Denis, M., Desabre, S., et al., 2001. A biogeochemical study of the island mass effect in the context of the iron hypothesis: Kerguelen Islands, Southern Ocean. Deep Sea Res. Oceanogr. Res. Pap. 48 (1), 163-187. https://doi.org/10.1016/S0967-0637(00)00047-9.

Blain, S., Quéguiner, B., Armand, L., Belviso, S., Bombled, B., Bopp, L., et al., 2007. Effect of natural iron fertilization on carbon sequestration in the Southern Ocean. Nature 446 (7139), 1070-1074. https://doi.org/10.1038/nature05700.

Bost, C.A., Cotté, C., Bailleul, F., Cherel, Y., Charrassin, J.B., Guinet, C., et al., 2009. The importance of oceanographic fronts to marine birds and mammals of the southern oceans. J. Mar. Syst. 78 (3), 363-376. https://doi.org/10.1016/j. jmarsys.2008.11.022.

Boyd, P.W., Ellwood, M.J., 2010. The biogeochemical cycle of iron in the ocean. Nat. Geosci. 3 (10), 675. https://doi.org/10.1038/ngeo964.

Boyd, P.W., Watson, A.J., Law, C.S., Abraham, E.R., Trull, T., Murdoch, R., et al., 2000. A mesoscale phytoplankton bloom in the polar Southern Ocean stimulated by iron fertilization. Nature 407 (6805), 695-702. https://doi.org/10.1038/35037500.

Boyd, P.W., Jickells, T., Law, C.S., Blain, S., Boyle, E.A., Buesseler, K.O., et al., 2007. Mesoscale iron enrichment experiments 1993-2005: synthesis and future directions. Science 315 (5812), 612-617. https://doi.org/10.1126/science.1131669.

Calinsky, T., Harabasz, J., 1974. A dendrite method for cluster analysis. Commun. Stat. Theor. Methods 3 (1), 1-27. Retrieved from. www.bogucki.com.pl.

Constable, A.J., Melbourne-Thomas, J., Corney, S.P., Arrigo, K.R., Barbraud, C., Barnes, D.K.A., et al., 2014. Climate change and Southern Ocean ecosystems I: how changes in physical habitats directly affect marine biota. Global Change Biol. 20 (10), 3004-3025. https://doi.org/10.1111/gcb.12623.

Cotté, C., Park, Y.H., Guinet, C., Bost, C.A., 2007. Movements of foraging king penguins through marine mesoscale eddies. Proc. Biol. Sci. 274 (1624), 2385-2391. https:// doi.org/10.1098/rspb.2007.0775.

De Baar, H.J.W., Boyd, P.W., Coale, K.H., Landry, M.R., Tsuda, A., Assmy, P., et al., 2005. Synthesis of iron fertilization experiments: from the iron age in the age of enlightenment. J. Geophys. Res. C Oceans 110 (9), 1-24. https://doi.org/10.1029/ 2004JC002601.
De Monte, S., Cotté, C., D’Ovidio, F., Lévy, M., Le Corre, M., Weimerskirch, H., 2012. Frigatebird behaviour at the ocean-atmosphere interface: integrating animal behaviour with multi-satellite data. J. R. Soc. Interface 9 (77), 3351-3358. https:// doi.org/10.1098/rsif.2012.0509.

Duhamel, G., Hulley, P.A., Causse, R., Koubbi, P., Vacchi, M., Pruvost, P., et al., 2014 Biogeographic patterns of fish. In: Biogeographic Atlas of the Southern Ocean, pp. 418-421.

D’Ovidio, F., Della Penna, A., Trull, T.W., Nencioli, F., Pujol, M.I., Rio, M.H., et al., 2015. The biogeochemical structuring role of horizontal stirring: Lagrangian perspectives on iron delivery downstream of the Kerguelen Plateau. Biogeosciences 12 (19), 5567-5581. https://doi.org/10.5194/bg-12-5567-2015.

Flierl, G.R., Davis, C.S., 1993. Biological effects of gulf stream meandering. J. Mar. Res. 51 (3), 529-560. https://doi.org/10.1357/0022240933224016.

Foster, S.D., Hill, N.A., Lyons, M., 2017. Ecological grouping of survey sites when sampling artefacts are present. J. Roy. Stat. Soc. Series C Appl. Stat, 66 (5), 1031-1047. https://doi.org/10.1111/rssc.12211.

Gandhi, N., Ramesh, R., Laskar, A.H., Sheshshayee, M.S., Shetye, S., Anilkumar, N., et al., 2012. Zonal variability in primary production and nitrogen uptake rates in the southwestern Indian Ocean and the Southern Ocean. Deep-Sea Res. Part I Oceanogr. Res. Pap. 67, 32-43. https://doi.org/10.1016/j.dsr.2012.05.003.

Graham, R.M., De Boer, A.M, van Sebille, E., Kohfeld, K.E., Schlosser, C., 2015. Inferring source regions and supply mechanisms of iron in the Southern Ocean from satellite chlorophyll data. Deep-Sea Res. Part I Oceanogr. Res. Pap. 104, 9-25. https://doi. org/10.1016/j.dsr.2015.05.007.

Grant, S., Constable, A., Raymond, B., Doust, S., 2006. Bioregionalisation of the Southern Ocean. Hobart.

Gutt, J., Bertler, N., Bracegirdle, T.J., Buschmann, A., Comiso, J., Hosie, G., et al., 2015. The Southern Ocean ecosystem under multiple climate change stresses - an integrated circumpolar assessment. Global Change Biol. 21 (4), 1434-1453. https:// doi.org/10.1111/gcb.12794.

Handegard, N.O., Buisson, L. Du, Brehmer, P., Chalmers, S.J., De Robertis, A., Huse, G., et al., 2013. Towards an acoustic-based coupled observation and modelling system for monitoring and predicting ecosystem dynamics of the open ocean. Fish Fish. 14 (4), 605-615. https://doi.org/10.1111/j.1467-2979.2012.00480.x.

Harris, P.T., Macmillan-Lawler, M., Rupp, J., Baker, E.K., 2014. Geomorphology of the oceans. Mar. Geol. 352, 4-24. https://doi.org/10.1016/j.margeo.2014.01.011.

Hill, N.A., Foster, S.D., Duhamel, G., Welsford, D., Koubbi, P., Johnson, C.R., 2017. Model-based mapping of assemblages for ecology and conservation management: a case study of demersal fish on the Kerguelen Plateau. Divers. Distrib. 23 (10), 1216-1230. https://doi.org/10.1111/ddi.12613.

Hogg, O.T., Huvenne, V.A.I., Griffiths, H.J., Linse, K., 2018. On the ecological relevance of landscape mapping and its application in the spatial planning of very large marine protected areas. Sci. Total Environ. 626, 384-398. https://doi.org/10.1016/j. scitotenv.2018.01.009.

Hosie, G., Fukuchi, M., Kawaguchi, S., 2003. Development of the Southern Ocean continuous plankton recorder survey. Prog. Oceanogr. 58 (2-4), 263-283. https:// doi.org/10.1016/j.pocean.2003.08.007.

Hosie, G., Mormède, S., Kitchener, J., Takahashi, K., Raymond, B., 2014. 10.3.Nearsurface zooplankton communities. In biogeographic atlas of the Southern Ocean (pp. $422-430$. 
Hunt, B.P., Hosie, G.W., 2003. The Continuous Plankton Recorder in the Southern Ocean: a comparative analysis of zooplankton communities sampled by the CPR and vertical net hauls along 140 E. J. Plankton Res. 25 (12), 1561-1579. https://doi.org/ 10.1093/plankt/fbg108.

Hunt, B.P.V., Hosie, G.W., 2006a. The seasonal succession of zooplankton in the Southern Ocean south of Australia, part I: the seasonal ice zone. Deep Sea Res. Oceanogr. Res. Pap. 53 (7), 1182-1202. https://doi.org/10.1016/j.dsr.2006.05.001. Hunt, B.P.V., Hosie, G.W., 2006b. The seasonal succession of zooplankton in the Southern Ocean south of Australia, part II: the sub-antarctic to polar frontal zones. Deep Sea Res. Oceanogr. Res. Pap. 53 (7), 1203-1223. https://doi.org/10.1016/j. dsr.2006.05.002.

Hunt, B.P.V., Pakhomov, E.A., Williams, R., 2011. Comparative analysis of 1980's and 2004 macrozooplankton composition and distribution in the vicinity of Kerguelen and Heard Islands: seasonal cycles and oceanographic forcing of long-term change. Cybium 35, 79-92. https://doi.org/10.26028/cybium/2011-35SP-008.

IPCC, 2019. In: Pörtner, H.-O., Roberts, D.C., Masson-Delmotte, V., Zhai, P., Tignor, M., Poloczanska, E., Mintenbeck, K., Alegría, A., Nicolai, M., Okem, A., Petzold, J., Rama, B., Weyer, N.M. (Eds.), IPCC Special Report on the Ocean and Cryosphere in a Changing Climate (in press).

Irigoien, X., Huisman, J., Harris, R.P., 2004. Global biodiversity patterns of marine phytoplankton and zooplankton. Nature 429 (6994), 863-867.

Kodinariya, T.M., Makwana, P.R., 2013. Review on determining number of Cluster in KMeans Clustering. International Journal of Advance Research in Computer Science and Management Studies 1 (6), 90-95.

Koubbi, P., 1993. Influence of the frontal zones on ichthyoplankton and mesopelagic fish assemblages in the Crozet Basin (Indian sector of the Southern Ocean). Polar Biol. 13 (8), 557-564. https://doi.org/10.1007/BF00236398.

Koubbi, P., Ozouf-Costaz, C., Goarant, A., Moteki, M., Hulley, P.-A., Causse, R., et al., 2010. Estimating the biodiversity of the east antarctic shelf and oceanic zone for ecoregionalisation: example of the ichthyofauna of the CEAMARC (collaborative east antarctic marine census) CAML surveys. Pol. Sci. 4 (2), 115-133. https://doi.org/ 10.1016/j.polar.2010.04.012.

Koubbi, P., Mignard, C., Causse, R., Da Silva, O., Baudena, A., Bost, C., et al., 2016. Ecoregionalisation of the Kerguelen and Crozet islands oceanic zone. Part II: the Crozet oceanic zone. CCAMLR Document, WG-EMM-16/54.

Koubbi, P., Moteki, M., Duhamel, G., Goarant, A., Hulley, P.A., O’Driscoll, R., et al., 2011. Ecoregionalization of myctophid fish in the Indian sector of the Southern Ocean: results from generalized dissimilarity models. Deep-Sea Res. Part II Top. Stud. Oceanogr. 58 (1-2), 170-180. https://doi.org/10.1016/j.dsr2.2010.09.007.

Koubbi, P., Guinet, C., Alloncle, N., Ameziane, N., Azam, C.S., Baudena, A., et al., 2016a. Ecoregionalisation of the Kerguelen and Crozet islands oceanic zone. Part I: introduction and Kerguelen oceanic zone. CCAMLR Document WG-EMM-16/43.

Lê, S., Josse, J., Husson, F., 2008. FactoMineR: an R package for multivariate analysis. J. Stat. Software 25 (1), 1-18.

Lehodey, P., Conchon, A., Senina, I., Domokos, R., Calmettes, B., Jouanno, J., et al., 2015. Optimization of a micronekton model with acoustic data. ICES (Int. Counc. Explor. Sea) J. Mar. Sci. 72 (5), 1399-1412.

Lévy, M., 2008. The modulation of biological production by oceanic mesoscale turbulence. In: Transport and Mixing in Geophysical Flows. Springer, Berlin, Heidelberg, pp. 219-261.

Longhurst, A.R., 2010. Ecological Geography of the Sea. Elsevier.

Machu, E., Garçon, V., 2001. Phytoplankton seasonal distribution from SeaWiFS data in the Agulhas Current system. J. Mar. Res. 59 (5), 795-812. https://doi.org/10.1357/ 002224001762674944 .

MacQueen, J., 1967. Some methods for classification and analysis of multivariate observations. Proc. Fifth Berkeley Symp. Math. Statis. Prob. 1 (14), 281-297. https://doi.org/10.1007/s11665-016-2173-6.

Martin, J.H., 1990. Glacial-interglacial CO2 change: the iron hypothesis. Paleoceanography 5 (1), 1-13.

McClain, C.R., Signorini, S.R., Christian, J.R., 2004. Subtropical gyre variability observed by ocean-color satellites. Deep Sea Res. Part II Top. Stud. Oceanogr. 51 (1-3), 281-301.

Meilland, J., Fabri-Ruiz, S., Koubbi, P., Monaco, C. Lo, Cotte, C., Hosie, G.W., et al., 2016. Planktonic foraminiferal biogeography in the Indian sector of the Southern Ocean: contribution from CPR data. Deep-Sea Res. Part I Oceanogr. Res. Pap. 110, 75-89. https://doi.org/10.1016/j.dsr.2015.12.014.

Morel, A., Claustre, H., Gentili, B., 2010. The most oligotrophic subtropical zones of the global ocean: similarities and differences in terms of chlorophyll and yellow substance. Biogeosciences 7 (10), 3139-3151. https://doi.org/10.5194/bg-7-3139. 2010.

Orsi, A.H., Whitworth, T., Nowlin, W.D., 1995. On the meridional extent and fronts of the Antarctic Circumpolar Current. Deep-Sea Res. Part I 42 (5), 641-673. https:// doi.org/10.1016/0967-0637(95)00021-W.

Oschlies, A., Garçon, V., 1998. Eddy-induced enhancement of primary production in a model of the North Atlantic Ocean. Nature (266). https://doi.org/10.1038/28373, 394(6690).

Park, Y.H., Gambéroni, L., Charriaud, E., 1991. Frontal structure and transport of the antarctic circumpolar current in the South Indian ocean sector, $40-80^{\circ} \mathrm{E}$. Mar. Chem. 35 (1-4), 45-62. https://doi.org/10.1016/S0304-4203(09)90007-X.
Park, Y.H., Gamberoni, L., Charriaud, E., 1993. Frontal structure, water masses, and circulation in the Crozet Basin. J. Geophys. Res. 98 (C7), 12361-12385. https://doi. org/10.1029/93jc00938.

Park, Y.H., Pollard, R.T., Read, J.F., Leboucher, V., 2002. A quasi-synoptic view of the frontal circulation in the Crozet Basin during the Antares-4 cruise. Deep-Sea Res. Part II Top. Stud. Oceanogr. 49 (9-10), 1823-1842. https://doi.org/10.1016/S09670645(02)00014-0.

Park, Y.H., Roquet, F., Durand, I., Fuda, J.L., 2008. Large-scale circulation over and around the northern Kerguelen plateau. Deep-Sea Res. Part II Top. Stud. Oceanogr. 55 (5-7), 566-581. https://doi.org/10.1016/j.dsr2.2007.12.030.

Pitcher, T.J., Morato, T., Hart, P.J., Clark, M.R., Haggan, N., Santos, R.S. (Eds.), 2008 Seamounts: Ecology, Fisheries and Conservation. John Wiley \& Sons.

Pollard, R.T., Read, J.F., 2001. Circulation pathways and transports of the Southern Ocean in the vicinity of the Southwest Indian ridge. J. Geophys. Res.: Oceans 106 (C2), 2881-2898. https://doi.org/10.1029/2000JC900090.

Pollard, R.T., Lucas, M.I., Read, J.F., 2002. Physical controls on biogeochemical zonation in the Southern Ocean. Deep-Sea Res. Part II Top. Stud. Oceanogr. 49 (16), 3289-3305. https://doi.org/10.1016/S0967-0645(02)00084-X.

Pollard, R.T., Venables, H.J., Read, J.F., Allen, J.T., 2007. Large-scale circulation around the Crozet Plateau controls an annual phytoplankton bloom in the Crozet Basin. Deep-Sea Res. Part II Top. Stud. Oceanogr. 54 (18-20), 1915-1929. https://doi.org/ 10.1016/j.dsr2.2007.06.012.

Pollard, R., Sanders, R., Lucas, M., Statham, P., 2007. The Crozet natural iron bloom and export experiment (CROZEX). Deep-Sea Res. Part II Top. Stud. Oceanogr. 54 (18-20), 1905-1914. https://doi.org/10.1016/j.dsr2.2007.07.023.

Pondaven, P., Fravalo, C., Ruiz-Pino, D., Tréguer, P., Quéguiner, B., Jeandel, C., 1998. Modelling the silica pump in the permanently open ocean zone of the Southern Ocean. J. Mar. Syst. 17 (1-4), 587-619.

Pörtner, H.O., Peck, L., Somero, G., 2007. Thermal limits and adaptation in marine Antarctic ectotherms: an integrative view. Phil. Trans. Biol. Sci. 362 (1488), 2233-2258. https://doi.org/10.1098/rstb.2006.1947.

Post, A.L., Meijers, A.J.S., Fraser, A.D., Meiners, K.M., Ayers, J., Bindoff, N., et al., 2014. Environmental setting. In: Biogeographic Atlas of the Southern Ocean, pp. 418-421.

R Core Team, 2018. R: a language and environment for statistical computing. Retrieved from. https://www.r-project.org/.

Raymond, B., 2014. Pelagic regionalisation. In: Biogeographic Atlas of the Southern Ocean, pp. 418-421.

Reygondeau, G., Huettmann, F., 2014. Past, present and future state of pelagic habitats in the Antarctic Ocean. Biogeogr. Atls South. Ocean. 397-403.

Ropert-Coudert, Y., Hindell, M.A., Phillips, R.A., Charrassin, J.B., Trudelle, L., Raymond, B., 2014. Biogeographic patterns of birds and mammals. In: Biogeographic Atlas of the Southern Ocean, pp. 418-421.

Roquet, F., Park, Y.H., Guinet, C., Bailleul, F., Charrassin, J.B., 2009. Observations of the fawn trough current over the Kerguelen plateau from instrumented elephant seals. J. Mar. Syst. 78 (3), 377-393. https://doi.org/10.1016/j.jmarsys.2008.11.017.

Sanial, V., van Beek, P., Lansard, B., D'Ovidio, F., Kestenare, E., Souhaut, M., et al., 2014. Study of the phytoplankton plume dynamics off the Crozet Islands (Southern Ocean): a geochemical-physical coupled approach. J. Geophys. Res.: Oceans 119 (4), 2227-2237. https://doi.org/10.1002/2013JC009305.

Sokolov, S., Rintoul, S.R., 2007. On the relationship between fronts of the Antarctic Circumpolar Current and surface chlorophyll concentrations in the Southern Ocean. J. Geophys. Res.: Oceans 112 (7), 1-17. https://doi.org/10.1029/2006JC004072.

Sokolov, S., Rintoul, S.R., 2009. Circumpolar structure and distribution of the antarctic circumpolar current fronts: 1 . Mean 98 circumpolar paths. J. Geophys. Res.: Oceans 114 (11), 1-19. https://doi.org/10.1029/2008JC005108.

Spalding, M.D., Fox, H.E., Allen, G.R., Davidson, N., Ferdaña, Z.A., Finlayson, M., et al., 2007. Marine ecoregions of the world: a bioregionalization of coastal and shelf areas. Bioscience 57 (7), 573-583. https://doi.org/10.1641/B570707.

Takahashi, K.T., Kawaguchi, S., Kobayashi, M., Hosie, G.W., Fukuchi, M., Toda, T., 2002. Zooplankton distribution patterns in relation to the antarctic polar front zones recorded by continuous plankton recorder (CPR) during 1999/2000 kaiyo maru cruise. Polar Biosci 15, 97-107. https://doi.org/10.1016/j.polar.2011.04.003.

Takahashi, K.T., Hosie, G.W., Kitchener, J.A., McLeod, D.J., Odate, T., Fukuchi, M., 2010. Comparison of zooplankton distribution patterns between four seasons in the Indian Ocean sector of the Southern Ocean. Pol. Sci. 4 (2), 317-331. https://doi.org/ 10.1016/j.polar.2010.05.002.

Takahashi, K.T., Hosie, G.W., McLeod, D.J., Kitchener, J.A., 2011. Surface zooplankton distribution patterns during austral summer in the Indian sector of the Southern Ocean, south of Australia. Pol. Sci. 5 (2), 134-145. https://doi.org/10.1016/j. polar.2011.04.003.

Turner, J., Barrand, N.E., Bracegirdle, T.J., Convey, P., Hodgson, D.A., Jarvis, M., et al., 2014. Antarctic climate change and the environment: an update. Polar Rec. 50 (3), 237-259. https://doi.org/10.1017/S0032247413000296.

Venkataramana, V., Anilkumar, N., Naik, R.K., Mishra, R.K., Sabu, P., 2019. Temperature and phytoplankton size class biomass drives the zooplankton food web dynamics in the Indian Ocean sector of the Southern Ocean. Polar Biol. 42 (4), 823-829. https:// doi.org/10.1007/s00300-019-02472-w. 